\title{
BEHAVIOUR, WELFARE AND PERFORMANCE OF BROILER CHICKS FED DIETARY ESSENTIAL OILS AS GROWTH PROMOTER
}

\author{
SAMEH G.A. RAMADAN
}

Department of Husbandry and of Animal Wealth Development, Faculty of Veterinary Medicine, Menofia University, Sadat Branch, Egypt.

\section{ABSTRACT}

Received at: $26 / 2 / 2013$

One hundred fifty day-old Ross broiler chicks were used in this experiment. Chicks were weighed on arrival and randomly assigned to five dietary treatments (15 birds per pen) with two replicates for each treatment. The dietary treatments were consists of basal diet without additive (control), basal diet supplemented with $200 \mathrm{mg} / \mathrm{kg}$ essential oils of garlic (garlic group), basal diet supplemented with $200 \mathrm{mg} / \mathrm{kg}$ essential oils of ginger (ginger group), basal diet supplemented with $200 \mathrm{mg} / \mathrm{kg}$ essential oils of thyme (thyme group) and the (anti biotic group) which received Accepted: 14/4/2013 basal diet supplemented with $10 \mathrm{~g} / \mathrm{kg}$ zinc bacitracin. Dietary treatment started from day one to day 46 of age. Behavioral observation was carried out twice daily, two days a week for 6 consecutive weeks. Body weight (BW) and Feed intake per pen were measured weekly, from which body weight gain (BWG) and feed conversion ratio (FCR) were measured. At the end of experiment, fear responses, differential leucocytic count, $\mathrm{Hb}, \mathrm{PCV}$ and selected visceral organs were assayed. Also, dead birds and those showed lameness were recorded. Results revealed that birds in garlic and thyme exhibited higher feeding behavior. Control birds showed less resting, more walking and standing behaviors. BW, BWG and FCR were significantly influenced by dietary treatments. Garlic and thyme improved productive performance and could be used as alternative for an antibiotic growth promoter. Ginger group showed worst productive performance, however it not differed significantly from control group. Ginger at $200 \mathrm{mg} / \mathrm{kg}$ is not suitable feed additives as growth promoter. Garlic group showed highest bursal weight and lowest liver weight. Supplementation of diet with essential oils (garlic, ginger and thyme) and antibiotic resulted in improved welfare (reduce stress and decrease fear responses). Dietary treatments had neither effect on percentage of birds showed lameness nor died ones.

Key words: Broilers; Behavior; Performance; Essential oil; Fear; Stress.

\section{INTRODUCTION}

In the recent years, there has been a pronounced trend towards the intensification of methods of poultry keeping. The welfare problems of broiler chickens was a matter due to high densities of birds in broiler house and their selection for rapid growth, where feeding, drinking, walking, scratching, pecking and dustbathing were inhibited while time lying down, resting and sleeping increased (Vestergaard and Sanotra 1999).

Sub-therapeutic dosage of antibiotics has been used extensively as feed additives growth promoters in the poultry industry and other livestock feeds for several decades. A manipulation of gut function and microbial habitat of domestic animal has been recognized as an important tool for improving growth performance and feed efficiency (Collington et al., 1990) and control of zoonotic pathogens such as Salmonella, Campylobacter, Escherichia coli and Enterococci species in the gut (NOAH, 2001). Recently, the concerns about possible antibiotic residues and antibiotic resistance have aroused great caution in the usage of antibiotics in the animal industry (Donoghue, 2003), and led to the ban of these products by the European Union in January 2006. This decision has therefore stimulated a search for alternative feed-additives including probiotics, prebiotics, enzymes, and plant extracts in animal feeding (Demir et al., 2003; Hernandez et al., 2004; Sarica et al., 2005). In this view, aromatic plants and oils extracted from these plants are becoming more important due to their antimicrobial effects (Dorman and Deans 2000), antioxidative potential (Hui 1996) and the stimulating effect on animal digestive system 
(Brugalli 2003) and immune system (Mikulski et al., 2008). It is in this respect that essential oils from garlic (Allium sativum), ginger (Zingiber officinale) and thyme (Thymus vulgaris) supplements were evaluated in the current study as natural alternatives to feed antibiotics in broiler diets.

Garlic (Allium sativum) was known as spice and herbal medicine for prevention and treatment of a verity of diseases (Adibmoradi et al., 2006; Javandel et al., 2008) as well as growth promoter (Ali and Zahran, 2010) and improves productive performance in broiler chickens (Demir et al., 2003; Tollba and Hassan, 2003). Garlic has antimicrobial, antioxidant as well as antihypertensive properties (Sivam, 2001) and lower serum and liver cholesterol (Qureshi et al., 1983). These functions were attributed to bioactive components present in garlic (Amagase et al., 2001) including sulpher containing compound such as allin, diallylsulpher and allicin (Amagase and Milner, 1993).

Thyme (Thymus vulgaris) was a popular medicinal plant mostly grown in Mediterranean regions (Toghyani et al., 2010). Thymol and cavarcrol were the major component isolated from essential oil of thyme, which have positive effect on growth performance in broilers (Allen et al., 1998 and Denil et al., 2004) and antibacterial, anticoccidial, antifungal and potent antioxidant properties (Aesschbach et al., 1994; Vincent, 2002; Hagmuller et al., 2006).

Ginger (Zingiber officinale) is an herb used as a spice for over 2000 years (Stoilova et al., 2007) also utilized frequently in traditional oriental medicine for the treatment of a wide range of diseases (Badreldin et al., 2008). Ginger has antioxidant, antimicrobial, and anti inflammatory properties (Butt and Sultan 2011) and exert substantial anticarcinogenic and antimutagenic activities (Lee and Surh, 1998).

Fear is regarded as a powerful emotion that exerts a progressive inhibitory effect on behaviour patterns generated by all other motivational systems (Jones, 1987, 1996). The increased intensity of fear response can seriously affect the welfare and performance indicators in poultry, including growth, food conversion efficiency, egg production and product quality (Jones, 1996; Faure et al., 2003). Fear can be assessed by duration of the tonic immobility reaction (TI) as a measure (Jones, 1986). Tonic immobility is a variable period of immobility induced by manual restraint. A long duration of TI is thought to be indicative of high levels of fearfulness, and a short duration is indicative of low levels of fearfulness (Jones, 1986). Many studies have noted that the heterophil/ lymphocyte (H/L) ratio was affected by stressors and could be used as an indicator of stress in birds (Gross and Siegel 1983; Maxwell 1993; Maxwell and Robertson 1998). Zulkifli et al. (2003) reported that the heterophil lolymphocyte ratio (H:L) is a reliable indicator of avian stress. The $\mathrm{H}$ : $\mathrm{L}$ ratio increased with heat stress in broiler chicks (McFarlane and Curtis 1989), feed restriction (Maxwell et al., 1991), high stocking density (Martrenchar et al., 1997; Feddes et al., 2002), chronic bacterial infections, stress and trauma (Lane 1987).

The objective of this study was to investigate the effects of essential oils of garlic, ginger and thyme as alternative to antibiotic (zinc bacitracin) on the behaviour, welfare (fear and stress), growth performance, some carcass characteristics and some blood parameters of broiler chicks.

\section{MATERIALS and METHODS}

\section{Experimental birds}

One hundred fifty day-old Ross broiler chicks were purchased from commercial hatchery. Chicks were weighed on arrival and randomly assigned to five dietary treatments. Each treatment was housed in wood shaving bedded floor pen (15 birds per pen) with two replicates for each treatment. The light regimen in the house was $23 \mathrm{~h}$ light: $1 \mathrm{~h}$ dark. Temperature was reduced from $32{ }^{\circ} \mathrm{c}$ during the first week of life to $25{ }^{\circ} \mathrm{c}$ at three weeks and was then kept constant. Food and water were provided ad libitum. Birds fed on commercial ration free from antibiotics obtained from International Company for Feed and Animal Production (IFAP). The composition and nutrient content of the basal diets is shown in table 1. The diet was subjected to chemical analysis to meet the nutrient requirements recommended by National Research Council (NRC 2004). The dietary treatments were consists of basal diet without additive (control), basal diet supplemented with $200 \mathrm{mg} / \mathrm{kg}$ essential oils (EO) of garlic (Allium sativum- garlic group), basal diet supplemented with $200 \mathrm{mg} / \mathrm{kg}$ EO of ginger (Zingiber officinale- ginger group), basal diet supplemented with $200 \mathrm{mg} / \mathrm{kg}$ EO of thyme (Thymus vulgaris- thyme group) and the antibiotic group received basal diet supplemented with $10 \mathrm{~g} / \mathrm{kg}$ zinc bacitracin. Dietary treatment started from day one to day 46 of age (end of the experiment). Essintial oils of garlic, ginger and thyme were considered pure $100 \%$ and were commercially purchased (Haraz El-Attar, Egypt). A standard vaccination program was applied during the whole period for all treatments group. 


\section{Measurements}

\subsection{Behavioral observations}

Chicks of each group were directly observed in two periods, each of four hrs, one period was in the morning (7.00-11.00) and the other period was in the afternoon (13.00-17.00). Each group was observed for 15 minutes in each observation period by a person who was sitting outside of the pen on a high chair, with a good view over the whole pen. Before starting to observe a pen of birds, the observer sat quietly for $5 \mathrm{~min}$. to get the birds accustomed to his presence. Instantaneous scan sampling observations of chick's behavior were performed according to Lee and Craig (1990). For each scan the number of chicks engaged in nine mutually exclusive activities were recorded every 60 seconds (feeding, drinking, resting, walking, standing, foraging, preening, wing related behaviors as wing/leg stretching and/or wing flapping, and feather pecking). A detailed description of those parameters is presented in Table 2. The percentage of chicks engaged in each behavior was calculated during all scan samples in each pen. Behavioral observations were carried out twice daily, two days per week for six consecutive weeks.

\subsection{Performance}

Body weight (BW) and feed intake (FI) per pen were measured weekly. Ten birds from each pen were marked at the end of the first week and then were individually weighed weekly till the end of the experiment. Body weight gain (BWG) and feed conversion ratio (FCR) were calculated for each treatment. At forty six days of age, four birds per replicate were randomly chosen, slaughtered and their liver, gizzard, heart and lymphoid organs (spleen and bursa of fabricius) were collected, weighed and calculated as a percentage of live body weight.

Mortality and lameness were recorded for each pen.

\subsection{Hematological parameters.}

At the $46^{\text {th }}$ day of age, blood samples were collected from wing vein of five chicks from each pen (10 chicks per treatment). The blood was received into EDTA anticoagulant for the determination of hemoglobin content $(\mathrm{Hb})$ and packed cell volume (PCV) using the methods described by Wintrobe (1976). Blood smears were prepared. After drying the smears were stained using May-Grunewald-Giemsa stain. One hundred leucocytes, including heterophils, esinophils, lymphocytes, and monocytes were counted at $\times 40$ (oil immersion lens) and $\mathrm{H} / \mathrm{L}$ was calculated.

\subsection{Tonnic immobility (fear test).}

Tonic immobility (TI) reaction was assessed on six birds per replicate. Assessment was conducted in a quite room separate from the rearing pens. Each bird was restrained on its back in a U-shaped wooden cradle covered with several layers of clothing (Jones and Faure 1981) with the head hanging, with firm but gentle pressure on the sternum for 10 seconds. If the bird remained immobile for 10 seconds after the experimenter removed his hands, a stopwatch was started to record latencies until the bird right itself. If the bird righted itself in less than 10 seconds, it was considered that tonic immobility had not been induced, and the restraint procedure was repeated. If the bird did not show a righting response over a 5min test period, a maximum score of 300 seconds was given for righting time (Mills and Faure, 1991). If TI was not induced after three attempts the duration of TI was considered 0 seconds. (Zulkifli et al., 2000).

\section{Statistical analysis}

Data collected were subject to analysis of variance and where significant differences were observed means were further subjected to Duncan's multiple range, using SPSS for Windows: 10.1, SPSS inc. (1999). The results were considered as significant when P- values less than 0.05 and 0.01 .

Percentage of birds showed lameness and those died were analyzed by Chi Square.

\section{RESULTS and DISCUSSION}

\section{Behavioral patterns}

The effects of dietary supplementation of medicinal plant essential oils and antibiotic on broilers behaviors are presented in Table 3. A significantly higher proportion of chicks in garlic group were engaged in feeding behavior $13.19 \pm 1.95$ compared to control group $7.61 \pm 1.33$ (mean \pm SE respectively, $\mathrm{p}=.001$ ) with anti biotic group being intermediary but not different from them $(11.20 \pm 1.58)$, which in turn was reflected in final body weight and other productive performance of chicks. This result was in accordance with Poulair et al. (2010) who found that, garlic powder improved average daily feed intake in broiler chickens. In the same trend, Javed et al. (2009) reported that feed intake was improved when broilers were supplemented with aqueous extract of medicinal plants containing garlic $(10 \mathrm{ml} / \mathrm{L}$ of drinking water). Contrary, Aji et al. (2011) mentioned that administration of $100 \mathrm{mg}$ of garlic not affect feed intake of broiler chickens. Also, Ashayerizadaeh et al. (2009); Onibi et al. (2009); Mohebbifar and Torki (2011) found no effect of garlic powder supplementation on feed intake of broiler chicks.

Feeding behavior was significantly higher in thyme group compared to control group $13.63 \pm 1.56,7.61$ \pm 1.33 (mean \pm SE respectively, $\mathrm{p}=.001$ ) with antibiotic group being intermediary but not different from them (Table 3). This result is in accordance with Foroughi et al. (2011) who reported that the birds were fed diet contains $180 \mathrm{mg} / \mathrm{kg}$ essential oils of thyme had the highest value of feed intake. Also, Al- 
Kassie and Jameel (2009) found that supplementation of diet with 100 and $200 \mathrm{mg} \mathrm{kg}$ thyme oil improved feed intake. On the other hand, Najafi and Torki (2010); Toghyani et al. (2010) and Rahimi et al. (2011) indicated that diet supplemented with thyme had no effect on feed intake in broilers.

Results of feeding behavior (Table3) indicated that percentage of birds engaged in feeding behavior in antibiotic group $11.20 \pm 1.58$ was not significantly different from control, garlic and thyme groups 7.61 $\pm 1.33,13.19 \pm 1.95,13.63 \pm 1.56$ respectively (mean $\pm \mathrm{SE}, \mathrm{p}>.05)$. This result was in agreement with Rahimi et al. (2011) who found no significant difference in feed consumption between chicks feed basal diet (control), basal diet supplemented with 15 ppm virginiamycin, $0.1 \%$ aqueous extract of thyme or $0.1 \%$ aqueous extract of garlic. Similar results were reported by Songsang et al. (2008) and Toghyani et al. (2010).

Results presented in Table 3. indicated that chicks in ginger group exhibited significantly lower feeding behavior $(3.75 \pm .97$, mean $\pm \mathrm{SE}, \mathrm{p}=0.001)$ compared to chicks in other groups except control birds. Contrary to our result, Arshad et al. (2012) mentioned that ginger extract at 40 and $50 \mathrm{ml} /$ liter of drinking water significantly increase feed intake in broiler chicks compared to control birds. Also, Dieumou et al. (2009) found no significant difference in feed intake between broiler chicks fed basal diet (control) and those fed basal diet supplanted with ginger and garlic essential oils.

In consistency among the results in different studies might be due to different usage of medicinal plants sources, forms (powder, leaves, aqueous extraction, and essential oil), dose, diet, management and environmental conditions.

Results from behavioral observations in the present study indicated that dietary supplementation of essential oils and anti biotic significantly affects the proportion of birds engaged in resting, standing and movement behaviors (Table 3). Birds in unsuppleminted diet control group were showed significantly less resting behavior $54.40 \quad \pm 3.88$ compared to birds in garlic, ginger, thyme and antibiotic groups $64.87 \pm 3.03,66.10 \pm 2.17,63.76$ $\pm 2.97,66.30 \pm 2.88$, respectively (mean $\pm \mathrm{SE}$, $\mathrm{p}=.035$ ). Percentage of birds engaged in walking behavior was significantly higher in control birds $7.42 \pm 1.26$ compared to birds in garlic, thyme and anti biotic groups $4.33 \pm .83,3.49 \pm .89,3.26 \pm .71$ respectively (mean $\pm \mathrm{SE}, \mathrm{p}=.004$ ). The percentage of birds engaged in standing behavior was significantly higher in control and ginger groups $12.07 \pm 1.62$, $12.75 \pm 1.63$, respectively (mean $\pm \mathrm{SE}, \mathrm{p}=.001$ ) compared to birds in garlic, thyme and antibiotic groups $(5.65 \pm 1.08,7.14 \pm 1.15,7.87 \pm 1.45$, respectively, mean $\pm \mathrm{SE})$. Increased walking and standing behaviors in control and ginger supplemented birds may be related to low feeding behavior that demonstrated in these groups. Hocking et al. (1997) reported that pacing was negatively related to rate of consumption. Moreover, Hocking (1993) observed that the proportion of time spent standing and walking was associated with a decrease in the proportion of time involved in eating, scratching and pecking activities.

Results summarized in Table (3) showed non significant differences of dietary treatment on the percentage of birds engaged in drinking, foraging, preening, wing stretching and/or wing flapping and feather pecking.

\section{Productive performance:}

In the present study, body weights (BW), body weight gain (BWG) and feed conversion ratio (FCR) were significantly influenced by the addition of essential oils and antibiotic to diets (Table 4). At the $46^{\text {th }}$ day of age birds in garlic group had significantly higher BW $2181.67 \pm 51.63$ compared to birds in control and ginger groups $1926.00 \pm 63.13,1789.17$ \pm 73.97 respectively (mean $\pm \mathrm{SE}, \mathrm{p}=.001$ ) but not significantly differed from birds in thyme and antibiotic groups. Garlic group had significantly increased BWG at 21-46 days of age 1549.67 \pm 47.19 compared to control and ginger groups $1298.00 \pm$ $65.13,1161.17 \pm 74.21$ respectively (mean \pm SE, $\mathrm{p}=.011)$. Also, Garlic group had significantly higher BWG in the whole period (0-46 days) 2140.19 \pm 84.56 compared to control and ginger groups $1882.69 \pm 57.73,1746.03 \pm 62.41$ respectively (mean \pm SE, $\mathrm{p}=.008$ ). Results in Table 4 indicated that, garlic improves FCR at 21-46 days of age 2.44 \pm .05 compared to control and ginger groups $2.82 \pm .08$, $2.94 \pm .10$ respectively (mean $\pm \mathrm{SE}, \mathrm{p}=.007$ ). Similar results were showed in the whole period (0-46 days) as FCR was significantly better in garlic group 2.28 \pm .03 compared to control and ginger groups 2.61 $\pm 0.05,2.69 \pm .06$ respectively (mean $\pm \mathrm{SE}, \mathrm{p}=.001$ ). Garlic in this study improves final body weight, BWG and FCR. Similar results were reported by Tollba and Hassan (2003). Also, many authors indicated positive effect of garlic on productive performance including FCR and BWG (Mahmood et al., 2009; Pourali et al., 2010), BW and FCR (Javed et al., 2009; Mansoub 2011), BWG (Aji et al., 2011; Kumar et al., 2010). The improvement in broiler performance could attribute to active ingredient in garlic. Lewis et al. (2003) reported that garlic contain allicin, which promotes the performance of intestinal flora, thereby improving digestion and enhancing the utilization of energy. Also, Ramakrishna et al. (2003) suggested that garlic supplementation enhance the activity of pancreatic enzymes and provides an environmental for better absorption of nutrients. Contrary to results in the current study, Songsang et al. (2008); Onibi et al. (2009); Rahmatnejad et al. (2009); Issa and AboOmar (2012) found no effect of garlic on broilers 
BWG and FCR. Similarly, Horton et al. (1991); Konjufca et al. (1997) and Dieumou et al. (2009) found no effect of garlic on broiler performance. Moreover, Ademola et al. (2009) concluded that during the finishing phase of growth of the chickens, $1.5 \%$ garlic and $2 \%$ ginger caused significant $(\mathrm{P}<0.01)$ decreases in final live body weight and BWG of the chickens.

Although antibiotic group showed significantly higher BWG at 0-21 days of age compared to garlic group $637.58 \pm 87.14,590.52 \pm 75.53$ respectively (mean \pm SE, $\mathrm{p}=.001$ ) (Table 4). Garlic group showed higher BWG than antibiotic group at 21-46 days of age $1549.67 \pm 47.19,1337.46 \pm 98.21$, respectively (mean $\pm \mathrm{SE}, \mathrm{p}=.011)$. Also, Garlic group showed significantly improved FCR compared to the antibiotic group at 21-46 days of age (2.44 $\pm .05,2.76$ \pm .07 , respectively, mean $\pm \mathrm{SE}, \mathrm{p}=.007$ ) and at $0-46$ days of age $(2.28 \pm .03,2.48 \pm .04$, respectively, mean $\pm \mathrm{SE}, \mathrm{p}=.001$ ) but not differed from thyme group at the same periods. These results were disagree with Rahimi et al. (2011) who reported that chicks fed diet supplemented with $15 \mathrm{ppm}$ virginiamycin had better BW, BWG and FCR than those fed diet supplemented with $0.1 \%$ aqueous extract of garlic.

Data summarized in Table 4. showed non significant difference in productive performance between thyme and anti biotic groups.

Birds in thyme and antibiotic groups had non significant higher final BW 2034.16 $\pm 41.48,2017.16$ \pm 43.27 respectively (mean \pm SE) compared to birds in control group $1926.00 \pm 63.13$ (mean \pm SE, $p>.05$ ) . The average BWG (g/bird) was significantly higher in the thyme and antibiotic groups at 0-21 days 621.73 $\pm 86.03,637.58 \pm 87.14$, respectively (mean $\pm \mathrm{SE}$, $\mathrm{p}=.001)$ compared to control group $593.69 \pm 39.02$ (mean $\pm \mathrm{SE}$ ). Thyme group had a non significant improved BWG compared to control and anti biotic group at 21-46 days, and in the whole period (0-46 days) compared to control group. Thyme group had significantly better FCR compared to control group at 0-46 days $(2.39 \pm .04,2.61 \pm 0.05$ respectively $\mathrm{p}=.001$ ), and non significant improved FCR compared to antibiotic group during the same period. Broilers received antibiotic had a non significant improved FCR compared to control group at 0-46 days (2.48 $\pm .04,2.61 \pm 0.05$ respectively, $\mathrm{p}>.05)$. Our results concerned with thyme and anti biotic were in agreement with Ciftci et al. (2009) who reported that 200 ppm thyme oil and antibiotic increased the daily live BWG and improved the FCR when compared with control group. In the same trend, Toghyani et al. (2010) indicated that, broilers received antibiotic and $5 \mathrm{~g} / \mathrm{kg}$ thyme had significantly higher BW compared to control birds and supplementing the diet with antibiotic resulted in significant improvement of FCR. Also, Al-kassie (2009); Najafi and Torki (2010) stated that, chicks fed basal diet supplemented with
$200 \mathrm{mg} / \mathrm{kg}$ thyme had significantly improved BWG and FCR compared to control birds. Antibiotics may control and limit the growth and colonization of a variety of pathogenic and nonpathogenic species of bacteria in chicks gut (Ferket, 2004). A more balanced biota population in gut could lead to a greater efficiency in digestibility and utilization of food, resulting in an enhanced growth and improved FCR (Bedford, 2000). In the current study, the improvement in broilers productive performance received $200 \mathrm{mg} / \mathrm{kg}$ EO of thyme could be attributed to active materials (thymol and caracerol) and its positive effect on nutrient digestibility (Langhout, 2000), their probable antioxidant and antibacterial effects in the intestine (Nascimento et al., 2000). Contrary to our results, Papageorgious et al. (2003) reported that essential oils were not effective in improving animal performance, and thymol did not improve poultry performance (Lee et al., 2004). Demier et al. (2005) indicated no differences in BWG and FCR of broilers fed diets supplemented with anti biotic growth promoter and five herbal feed additives from day 0 to 42 of age.

Birds supplemented with $200 \mathrm{mg} / \mathrm{kg}$ ginger essential oil had significantly lower BW at 46 days of age $1789.17 \pm 73.97$, compared to birds in garlic, thyme and antibiotic groups $2181.67 \pm 51.63,2034.16$ $\pm 41.48,2017.16 \pm 43.27$ respectively (mean $\pm \mathrm{SE}$, $\mathrm{P}=.001$ ), but not significantly differed from control birds.

Ginger group had the worst BWG $1746.03 \pm 62.41$ in the whole period 0-46 days compared to garlic, thyme and antibiotic groups $2140.19 \pm 84.56,1991.89$ $\pm 69.09,1975.04 \pm 82.47$ respectively (mean \pm SE, $\mathrm{P}=.008$ ), but not significantly differed from control group.

FCR (Table 4) was worst in ginger group compared to garlic, thyme and antibiotic groups through out the experiment especially in the whole period (0-46 days) $2.69 \pm .06,2.28 \pm .03,2.39 \pm .04,2.48 \pm .04$ (mean \pm $\mathrm{SE}$, respectively for control, garlic, thyme and antibiotic groups, $\mathrm{P}=.001)$. FCR was not significantly differed in ginger group compared to control one through out the experiment. Results in the current study were disagree with Arshad et al. (2012) who observed that broiler chicks received Ginger extract at 30, 40 and $50 \mathrm{ml} /$ liter of drinking water gained significantly $(\mathrm{P}<0.05)$ higher body weight and had significantly improved the over all performance than control birds.

It is obviously from the previous data that ginger EO $200 \mathrm{mg} / \mathrm{kg}$ is not a suitable feed additives alternative for antibiotics as a growth promoter in broilers.

Dietary treatment had non significant effect on percentage of bird's mortality as well as lameness (table 4). 
The wide range of performance results may be attributed to the dose, form, duration of processing of medicinal plants and experimental condition.

\section{Effect of dietary treatments on some carcass traits}

Effect of dietary supplementation with some essential oils and antibiotic on some edible organs (Gizzard, liver and heart) and lymphoid organs (spleen and bursa) at the end of the experiment are presented in Table 5. It was observed that percent of live weight of gizzard, heart and spleen not significantly differed by dietary treatment. Garlic group had significantly lower percent of liver weight $1.99 \pm .09$ compared to the control, ginger and antibiotic groups $2.53 \pm .09$, $2.92 \pm .23,2.91 \pm .05$ respectively, (mean $\pm \mathrm{SE}$, $\mathrm{P}=.001$ ) but not differed than thyme group. Thyme group had significantly lower liver weight $2.19 \pm .10$ compared to ginger and antibiotic groups $2.92 \pm .23$, $2.91 \pm .05$ respectively, (mean $\pm \mathrm{SE}, \mathrm{P}=.001$ ). Garlic group had significantly higher weight of bursa 0.13 \pm .01 compared to control, ginger, thyme and antibiotic groups $0.05 \pm .01,0.07 \pm .01,0.08 \pm .01,0.06$ \pm .01 respectively, (mean $\pm \mathrm{SE}, \mathrm{P}=.001$ ). Results in this experiment concerned with gizzard, heart and spleen were in accordance with many authors but results of liver and bursa were disagree with the same authors. Tolba and Hassan (2003); Issa and AboOmar (2012); Onibi et al. (2009) and Mahmood et al. (2009) found no effect of garlic supplementation on carcass traits including liver, heart, gizzard, and spleen. Also, Denli et al. (2004); Najafi and Torki (2010) and Toghyani et al. (2010) found no significant effect of thyme on carcass traits. Our result from bursa was in agreement with Rahimi et al. (2011) who reported that Relative weight of bursa fabricius in the garlic group showed a significantly more increase as compared with control, antibiotic and thyme groups. Also, our result from liver was in harmony with Dieumou et al. (2009) who found that relative liver weight of birds decreased $(\mathrm{P}<0.05)$ in garlic oil treatment compared with those given ginger oil and control.

\section{Effect of dietary treatments on differential leukocytic count, $\mathrm{Hb}$ and PCV.}

Table 6. Shows the effects of dietary treatments on differential leukocytic count, $\mathrm{Hb}$ and PCV. The present study showed that groups fed $200 \mathrm{mg} / \mathrm{kg}$ oil extract derived from garlic, ginger and thyme or supplemented with anti biotic had significantly lower heterophil $7.66 \pm 1.20,11.50 \pm 1.25,8.25 \pm .85,10.25$ \pm .47 respectively, (mean $\pm \mathrm{SE}$ ) compared to control group $16.00 \pm .57$ (mean $\pm \mathrm{SE}, \mathrm{p}=.001)$. $\mathrm{H} / \mathrm{L}$ ratio was significantly higher in control birds $0.19 \quad \pm .02$ compared to garlic, ginger, thyme and antibiotic groups $0.09 \pm .01,0.14 \pm .01,0.10 \pm .01,0.12 \pm .01$, respectively, (mean $\pm \mathrm{SE}, \mathrm{p}=.001$ ). These results indicated that control group were more stressed and supplementation of diet with essential oils or antibiotic reduced stress in broiler chicks. Maxwell (1993) mentioned that, stressed birds shown an increase in $\mathrm{H}$ : $\mathrm{L}$ ratios and this ratio may be a more reliable indicator of mild to moderate stress than plasma cortisone concentration. Stress in control birds was reflected on its productivity. These results were in accordance with Saxena and Madan (1997) who reported that, stress evokes harmful responses that interferes with the general health, productivity and resulted in immunosuppression. Results of this study were in agreement with Al-Kassie (2009) and Najafi and Torki (2010) they reported that, groups fed oil extract derived from thyme had significantly lower $\mathrm{H} / \mathrm{L}$ ratio. Also, Ali (2010) found supplementation of the broiler chickens diet with Thymus vulgaris leaves powder from 0 to 8 weeks of age resulted in significant $(\mathrm{p}<0.01)$ decrease in heterophil to lymphocyte ratio. On the other hand, Al-Beitawi et al. (2010) found that feed additives mixture from crushed Pimpinella anisum, Nigella sativa seeds and Thymus vulgaris significantly $(\mathrm{p}<.05)$ improve heterophils in male broiler chicks. Also, Toghyani (2010) found no significant effect of thyme powder or antibiotic supplementation on $\mathrm{H} / \mathrm{L}$ ratio. Moreover, Mohebbifar and Torki (2011) found no affected of garlic supplementation diet on heterophils in Ross broilers chicken.

Results of the current experiment indicated that $\mathrm{Hb}$ concentration (gm \%) not significantly affected by dietary supplementation (Table 6). Garlic and thyme groups had significantly more PCV\% $32.00 \pm 3.78$, $35.50 \pm .86$ respectively, (mean $\pm \mathrm{SE}$ ) compared to control, ginger and antibiotic groups $25.25 \pm 1.88$, $24.50 \pm 1.70,25.00 \pm .40$, respectively, (mean $\pm \mathrm{SE}$, $\mathrm{p}=.002)$. These results were in agreement with AlKassie (2009) and Ali (2010); they concluded that birds fed diet supplemented with thyme had significantly more $\mathrm{Hb}$ and $\mathrm{HCT}$. On the other hand, Toghyani et al. (2010) found no effect of antibiotic and thyme supplementation on $\mathrm{Hb}$ and HCT. Moreover, Rahimi et al. (2011) found no significant difference in $\mathrm{Hb}$ and HCT between control chicks and chicks fed diet supplemented with antibiotic, thyme and garlic. Also, Ademola et al. (2009) reported that dietary garlic, ginger and their mixtures did not affect the PCV and $\mathrm{Hb}$ concentration of the chickens.

\section{Effect of dietary treatments on fear responses (tonic immobility test- TI):}

Dietary supplementation with $200 \mathrm{mg} / \mathrm{kg}$ essential oils (garlic, ginger and thyme) and antibiotic had significant effect on the duration of tonic immobility (Table 7). The unsupplemented control birds were more fearful and showed significantly longer duration in TI test $234.16 \pm 26.86$ compared to garlic, ginger, thyme and antibiotic groups $108.66 \pm 27.53,78.50$ $\pm 39.34,102.83 \pm 34.48,124.33 \pm 32.03$ respectively, (mean $\pm \mathrm{SE}, \mathrm{p}=.002$ ). This result was in accordance with Jones (1986) who reported that a long duration of $\mathrm{TI}$ is thought to be indicative of high levels of 


\section{Assiut Vet. Med. J. Vol. 59 No. 137 April 2013}

fearfulness, and vice versa. Increased fear in control group resulted in poor productive performance in compare with other groups. Similarly, Jones (1996) and Faure et al. (2003) reported that increased intensity of fear response can seriously affect the welfare and performance in poultry.

Table 1: Composition of basal ration.

\begin{tabular}{ll}
\hline & Ingredient \\
\hline Crude protein \% & 22.06 \\
\hline Digestable energy Kcal/ kg of diet & 3079 \\
\hline Calcium \% & 1.2 \\
\hline Phosphorus \% & 0.44 \\
\hline Lysine \% & 0.75 \\
\hline Methionine and cystine \% & 0.82 \\
\hline
\end{tabular}

Table 2: Ethogram of behavior parameters recorded through observation of broiler chicken.

\begin{tabular}{ll}
\hline Ethogram & Definition \\
\hline Feeding & $\begin{array}{l}\text { Head extended towards available feed resources while beak in or above the } \\
\text { feeder appears to be manipulating or ingesting feed. }\end{array}$ \\
\hline Drinking & $\begin{array}{l}\text { Beak in contact with water in or above the drinker and appears to be drinking } \\
\text { water }\end{array}$ \\
\hline Westing & Sitting, lying or sleeping- with no other behaviour. \\
\hline Standing & Moving forward taking one or more steps. \\
\hline Foraging & $\begin{array}{l}\text { The abdomen is not touching the litter and the bird is motionless with no } \\
\text { other behaviour. }\end{array}$ \\
\hline preening & Pecking and Scratching the floor with feet. \\
\hline Wing-leg stretching and/or & $\begin{array}{l}\text { Beak related behaviour that beak touches the plumage of the bird itself. } \\
\text { Wing flapping }\end{array}$ \\
\hline Feather pecking & $\begin{array}{l}\text { Pecks and feathers of other birds } \\
\text { wings }\end{array}$ \\
\hline
\end{tabular}

Table 3: The influence of dietary treatments on the total number of chicks observed performing various behaviors (\% Means $\pm \mathrm{SE})$.

\begin{tabular}{|c|c|c|c|c|c|c|c|c|c|}
\hline Group & Feeding & Drinking & Resting & Walking & Standing & Foraging & Preening & $\begin{array}{c}\text { Wing st. } \\
\text { and/or wing } \\
\text { flapping }\end{array}$ & Pecking \\
\hline Control & $7.61^{b c} \pm 1.33$ & $3.46 \pm 1.14$ & $54.40^{\mathbf{b}} \pm 3.88$ & $7.42^{\mathrm{a}} \pm 1.26$ & $12.07^{\mathrm{a}} \pm 1.62$ & $3.45 \pm 1.60$ & $9.10 \pm 2.44$ & $2.11 \pm .58$ & $.64 \pm .36$ \\
\hline Garlic & $13.19^{\mathrm{a}} \pm 1.95$ & $3.70 \pm 1.13$ & $64.87^{\mathrm{a}} \pm 3.03$ & $4.33^{b c} \pm .83$ & $5.65^{\mathrm{b}} \pm 1.08$ & $1.65 \pm .57$ & $3.92 \pm .96$ & $2.64 \pm .77$ & $0.22 \pm .12$ \\
\hline Ginger & $3.75^{\mathbf{c}} \pm .97$ & $1.11 \pm .56$ & $66.10^{\mathrm{a}} \pm 2.17$ & $6.79^{\mathrm{ab}} \pm 1.08$ & $12.75^{\mathrm{a}} \pm 1.63$ & $.93 \pm .39$ & $6.95 \pm 1.05$ & $.76 \pm .36$ & $.99 \pm .51$ \\
\hline Thyme & $13.63^{\mathrm{a}} \pm 1.56$ & $3.30 \pm 1.07$ & $63.76^{\mathrm{a}} \pm 2.97$ & $3.49^{b c} \pm .89$ & $7.14^{\mathrm{b}} \pm 1.15$ & $1.97 \pm .52$ & $4.14 \pm .83$ & $2.59 \pm .68$ & $0.19 \pm .09$ \\
\hline Antibiotic & $11.20^{\mathrm{ab}} \pm 1.58$ & $1.70 \pm .75$ & $66.30^{\mathrm{a}} \pm 2.88$ & $3.26^{\mathrm{c}} \pm .71$ & $7.87^{\mathbf{b}} \pm 1.45$ & $1.32 \pm .52$ & $6.35 \pm 1.10$ & $1.96 \pm .61$ & $0.20 \pm .11$ \\
\hline p-value & .001 & Ns & .035 & .004 & .001 & ns & $\mathrm{ns}$ & $\mathrm{ns}$ & $\mathrm{ns}$ \\
\hline
\end{tabular}

${ }^{\mathrm{a}, \mathrm{b}}$ Means with the same letters and column are not significantly different. ns: non significant. 
$\underline{\text { Assiut Vet. Med. J. Vol. } 59 \text { No. } 137 \text { April } 2013}$

Table 4: The Effect of dietary supplementation on productive performance of broiler chicks.

\begin{tabular}{|c|c|c|c|c|c|c|}
\hline & Control & Garlic & Ginger & Thyme & Anti biotic & P-value \\
\hline \multicolumn{7}{|c|}{ Body weight (g/bird) } \\
\hline 1 day & $43.31 \pm .86$ & $41.48 \pm .53$ & $43.14 \pm .71$ & $42.27 \pm .94$ & $42.12 \pm .98$ & ns \\
\hline 21 days & $637.00 \pm 21.09$ & $632.00 \pm 17.06$ & $628.00 \pm 15.45$ & $664.00 \pm 13.69$ & $679.70 \pm 28.82$ & ns \\
\hline 46days & $1926.00^{\mathrm{bc}} \pm 63.13$ & $2181.67^{\mathrm{a}} \pm 51.63$ & $1789.17^{\mathrm{c}} \pm 73.97$ & $2034.16^{\mathrm{ab}} \pm 41.48$ & $2017.16^{\mathrm{ab}} \pm 3.27$ & .001 \\
\hline \multicolumn{7}{|c|}{ Body weight gain (g/bird) } \\
\hline $0-21$ days & $593.69^{b} \pm 39.02$ & $590.52^{b} \pm 75.53$ & $584.86^{\mathrm{b}} \pm 66.52$ & $621.73^{\mathrm{a}} \pm 86.03$ & $637.58^{\mathrm{a}} \pm 87.14$ & .001 \\
\hline $21-46$ days & $1298.00^{\mathrm{bc}} \pm 65.13$ & $1549.67^{\mathrm{a}} \pm 47.19$ & $1161.17^{\mathrm{c}} \pm 74.21$ & $1370.16^{\mathrm{ab}} \pm 59.56$ & $1337.46^{\mathrm{bc}} \pm 98.21$ & .011 \\
\hline $0-46$ days & $1882.69^{\mathrm{bc}} \pm 57.73$ & $2140.19^{a} \pm 84.56$ & $1746.03^{\mathrm{c}} \pm 62.41$ & $1991.89^{\mathrm{ab}} \pm 69.09$ & $1975.04^{\mathrm{ab}} \pm 82.47$ & .008 \\
\hline \multicolumn{7}{|c|}{ FCR (Feed intake/Gain) } \\
\hline $0-21$ days & $2.10^{\mathrm{ab}} \pm .08$ & $1.86^{\mathrm{b}} \pm .07$ & $2.18^{\mathrm{a}} \pm .08$ & $1.98^{\mathrm{ab}} \pm .07$ & $1.87^{\mathrm{b}} \pm .07$ & .049 \\
\hline $21-46$ days & $2.82^{\mathrm{ab}} \pm .08$ & $2.44^{\mathrm{c}} \pm .05$ & $2.94^{\mathrm{a}} \pm .10$ & $2.57^{b c} \pm .06$ & $2.76^{\mathrm{ab}} \pm .07$ & .007 \\
\hline $0-46$ days & $2.61^{\mathrm{ab}} \pm 0.05$ & $2.28^{\mathrm{d}} \pm .03$ & $2.69^{\mathrm{a}} \pm .06$ & $2.39^{\mathrm{cd}} \pm .04$ & $2.48^{b c} \pm .04$ & .001 \\
\hline $\begin{array}{l}\text { Mortality } \\
\%\end{array}$ & 6.66 & 0.00 & 0.00 & 0.00 & 0.00 & ns \\
\hline $\begin{array}{l}\text { Lameness } \\
\%\end{array}$ & 6.89 & 6.66 & 6.66 & 3.33 & 6.66 & ns \\
\hline
\end{tabular}

${ }^{\mathrm{a}, \mathrm{b}}$ Means with the same letters and column are not significantly different. ns: non significant.

Table 5: Effect of dietary treatments on some carcass traits at day 46.

\begin{tabular}{lcccccc}
\hline & Control & Garlic & Ginger & Thyme & Antibiotic & P-value \\
\hline Gizzard\% & $1.41 \pm .22$ & $1.63 \pm .05$ & $1.44 \pm .02$ & $1.48 \pm .17$ & $1.52 \pm .01$ & $\mathrm{~ns}$ \\
\hline Heart\% & $.48 \pm .01$ & $.41 \pm .03$ & $.44 \pm .03$ & $.48 \pm .05$ & $.50 \pm .07$ & $\mathrm{~ns}$ \\
\hline Liver\% & $2.53^{\mathrm{a}} \pm .09$ & $1.99^{\mathrm{c}} \pm .09$ & $2.92^{\mathrm{a}} \pm .23$ & $2.19^{\mathrm{bc}} \pm .10$ & $2.91^{\mathrm{a}} \pm .05$ & .001 \\
\hline Lymphoid organs & & & & & & \\
\hline Spleen \% & $.15 \pm .01$ & $.13 \pm .01$ & $.11 \pm .02$ & $.14 \pm .02$ & $.14 \pm .01$ & $\mathrm{~ns}$ \\
\hline Bursa \% & $.05^{\mathrm{b}} \pm .01$ & $.13^{\mathrm{a}} \pm .01$ & $.07^{\mathrm{b}} \pm .01$ & $.08^{\mathrm{b}} \pm .01$ & $.06^{\mathrm{b}} \pm .01$ & .001 \\
\hline
\end{tabular}

${ }^{\mathrm{a}, \mathrm{b}}$ Means with the same letters and column are not significantly different. ns: non significant.

Table 6: Effect of dietary treatments on differential leukocytic count, $\mathrm{Hb}$ and PCV.

\begin{tabular}{|c|c|c|c|c|c|c|}
\hline & Control & Garlic & Ginger & Thyme & Anti biotic & P-value \\
\hline Heterophil & $16.00^{\mathrm{a}} \pm .57$ & $7.66^{\mathrm{c}} \pm 1.20$ & $11.50^{b} \pm 1.25$ & $8.25^{\mathrm{c}} \pm .85$ & $10.25^{\mathrm{bc}} \pm .47$ & .001 \\
\hline Lymphocyte & $81.66 \pm 1.85$ & $84.67 \pm .88$ & $83.75 \pm 1.10$ & $85.75 \pm .94$ & $84.50 \pm .28$ & ns \\
\hline Monocyte & $3.00 \pm 1.15$ & $6.00 \pm 2.08$ & $2.75 \pm .25$ & $4.00 \pm .57$ & $3.00 \pm .40$ & ns \\
\hline Esinophil & $1.34 \pm .33$ & $3.33 \pm .88$ & $2.00 \pm .41$ & $2.00 \pm .40$ & $2.25 \pm .75$ & ns \\
\hline H/L ratio & $.19^{\mathrm{a}} \pm .02$ & $.09^{\mathrm{c}} \pm .01$ & $.14^{\mathrm{b}} \pm .01$ & $.10^{\mathrm{c}} \pm .01$ & $.12^{\mathrm{bc}} \pm .01$ & .001 \\
\hline $\mathrm{Hb}$ & $.48 \pm .06$ & $.51 \pm .01$ & $.52 \pm .03$ & $.59 \pm .02$ & $.58 \pm .05$ & $\mathrm{~ns}$ \\
\hline $\mathbf{P C V}$ & $25.25^{\mathrm{b}} \pm 1.88$ & $32.00^{\mathrm{a}} \pm 3.78$ & $24.50^{\mathrm{b}} \pm 1.70$ & $35.50^{\mathrm{a}} \pm .86$ & $25.00^{\mathrm{b}} \pm .40$ & .002 \\
\hline
\end{tabular}

${ }^{\mathrm{a}, \mathrm{b}}$ Means with the same letters and column are not significantly different. ns: non significant. 
Table 7: Effect of dietary treatments on fear responses (tonic immobility test-TI).

\begin{tabular}{ll}
\hline & TI duration (second) \\
\hline Control & $234.16^{\mathrm{a}} \pm 26.86$ \\
\hline Garlic & $108.66^{\mathrm{b}} \pm 27.53$ \\
\hline Ginger & $78.50^{\mathrm{b}} \pm 39.34$ \\
\hline Thyme & $102.83^{\mathrm{b}} \pm 34.48$ \\
\hline Anti biotic & $124.33^{\mathrm{b}} \pm 32.03$ \\
\hline p-value & 0.002 \\
\hline
\end{tabular}

${ }^{\mathrm{a}, \mathrm{b}}$ Means with the same letters and column are not significantly different.

\section{CONCLUSION}

In conclusion, use of herbal EO from garlic and thyme at dose of $200 \mathrm{mg} / \mathrm{kg}$ increased feeding behavior and improved productive performance (BW, WG and FCR) and could be used as natural alternatives to feed antibiotics in broiler diets. EO from ginger at the same dose is not a suitable feed additive alternative for antibiotic as a growth promoter. Supplementation of diet with EO (garlic, ginger and thyme) and antibiotic resulted in improved welfare (reduce stress and decrease fear responses).

\section{REFERENCES}

Ademola, S.G.; Farinu, G.O. and Babatunde, G.M. (2009): Serum lipid, growth and haematological parameters of broilers fed garlic, ginger and their mixtures. World Journal of Agricultural Sciences, 5 (1): 99-104.

Adibmoradi, M.; Navidshad, B.; Seifdavati, J. and Royan, M. (2006): Effect of Dietary Garlic Meal on Histological Structure of small Intestine in Broiler Chickens. Poultry Science, 43: 378-383.

Aeschbach, R.; Loliger, J.; Scott, B.C.; Muscia, A.; Butler, J. and Halliwell, B. (1994): Antioxidant action of thymol, carvacrol, 6ginerol, zinezerone and hydroxytyrosol. Food Chem. Toxicol., 32: 31-36.

Aji, S.B.; Kennedy, I.; Asha,' A.Y.A.; Joel, B.N.; Auwal, A.; Usman, A.; Muhammad, B.G.; Mohammed, A.I.; Haruna, A.; Mohammed, M.B.; Hama`, A.M.I. and Patrick, T.N. (2011): Effects of Feeding Onion (Allium cepa) and Garlic (Allium sativum) on Some Performance Characteristics of Broiler Chickens. Res. J. of Poult. Sci., 4: 22-27.

Al-Beitawi, A.N.; Safaa, S. and Mamoun, Z.A. (2010): Effect of adding crushed Pimpinella anisum, Nigella sativa seeds and Thymus vulgaris mixture to antibiotics-free rations of vaccinated and non-vaccinated male broilers on growth performance, antibody titer and haematological profile. Italian Journal of Animal Science, 9 (e43): 222-228.

Ali, N.A. (2010): influence of adding different levels of Thymus vulgaris leaves powder to the diet on certain blood traits of broiler chickens. 4th International Conference TAE 2010, Czech., University of Life Sciences Prague, page 107.

Ali, F.H. and Zahran, D.A. (2010): Effect of growth enhancers on quality of chicken meat during cold storage. Adv. J. Food Sci. Technol., 2: 219-226

Al-Kassie, G.A.M. (2009): Influence of two plant extracts derived from thyme and cinnamon on broiler performance. Pak. Vet. J. 29 (4): 169- 173.

Al-Kassie, G.A.M. and Jameel, Y.J. (2009): The effect of adding Thyme vulgaris and Cinnamomuim zeylanicum on productive performance in broilers. Proceeding of 9th Veterinary Scientific Conference, College Vet. Med., Univ. Baghdad, Iraq.

Allen, P.C.; Danforth, H.D. and Augustine, P.C. (1998): Diet modulation of avian coccidiosis. Int. J. Parasitol. 28: 1131-1140.

Amagase, H. and Milner, J.A. (1993): Impact of various sources of garlic and their constituents on 7, 12- dimethylbenzoa[a] anthracene binding to mammary cell DNA. Carcinogenesis, 14: 1627-1631.

Amagase, H.; Petesch, B.L.; Matsuura, H.; Kasuga, S. and Itakura, Y. (2001): Intake of garlic and its bioactive components. Journal of Nutrition, 131: 955-962.

Arshad, M.; Kakar, A.H.; Durrani, F.R.; Akhtar, A. and Niamatullah, M. (2012): Economical and immunological impact of Ginger (z. officinale) extract on broiler chicks. Pakistan Journal of Sciences, 64 (1). 46- 48.

Ashayerizadeh, A.; Dastar, B.; Rahmatnejad, E.; Shargh, M.S.; Ashayerizadeh, O. and Hossaini, S.M.R. (2009): Use of garlic (Allium sativum), black cumin seeds (Nigella sativa L.) and wild 
mint (Mentha longifolia) in broiler chickens diets. J. Anim. Vet. Adv., 8: 1860-1863.

Badreldin, A.; Blunden, G.; Tanira, M. and Nemmar, A. (2008): Some Phytochemical, Pharmacological and Toxicological Properties of Ginger (Zingiber officinale Roscoe): A Review of Recent Research. Food Chem. Toxicol., 46 (2): 409-420.

Bedford, M. (2000): Removal of antibiotic growth promoters from poultry diets: Implications and strategies to minimize subsequent problems. World's Poult. Sci. J. 56: 347-365.

Brugalli, I. (2003): Alimentação alternativa: a utilização de fitoterápicos ou nutracêuticos como moduladores da imunidade e desempenho animal. Anais do Simposio sobre Manejo e Nutrição de Aves e Suínos; Campinas, São Paulo. Brasil. Campinas: CBNA; pp.167-182.

Butt, M.S. and Sultan, M.T. (2011): Ginger and its health claims: molecular aspects. Crit. Rev. Food Sci. Nutr. 51 (5): 383-393.

Ciftci, M.; Guler, T.; Gulcihani, S.U.; Nihat, E.O.; Dalkilic, B. and Bicer, Z. (2009): The effect of thymus vulgaris 1 . oil as growth promoter in broilers. Indian Vet., J. 86 (9): 930-932.

Collington, G.K.; Park, D.S. and Armstrong, D.G. (1990): The Influence of Inclusion of Both an Antibiotic and a Probiotic in the Diet on the Development of Digestive Enzyme Activity in the Pig. Br. J. Nutr., 64: 59-70.

Demir, E.; Sarica, S.; Ozcan, M.A. and Suicmez, M. (2003): The use of natural feed additives as alternatives for an an-tibiotic growth promoter in broiler diets. British Poultry Science, 44, S44-S45.

Demir, E.; Sarica, S.; Özcan, M.A. and Suiçmez, M. (2005): The use of natural feed additives as alternative to an antibiotic growth promoter in broiler diets. Arch. fur Geflugelkunde, 69(3): 110-116

Denli, M.; Okan, F. and Uluocak, A.N. (2004): Effect of dietary supplementation of herb essential oils on the growth performance, carcass and intestinal characteristics of quail. South Africa. J. Anim. Sci., 34 (3): 174-179.

Dieumou, F.E.; Teguia, A.; Kuiate, J.R.; Tamokou, J.D.; Fonge, N.B. and Dongmo, M.C. (2009): Effects of ginger (Zingiber officinale) and garlic (Allium sativum) essential oils on growth performance and gut microbial population of broiler chickens. Live Stock Research for Rural Development. 21 (8): 25-34.

Donoghue, D.J. (2003): Antibiotic residues in poultry tissues and eggs: Human health concerns? Poultry Science, 82 (4): 618-621.

Dorman, H.J.D. and Deans, S.G. (2000): Antimicrobial agents from plants: antibacterial activity of plant volatile oils. Journal of Applied Microbiology 88: 308-316.

Faure, J.M.; Bessei, W. and Jones, R.B. (2003): Direct selection for improvement of animal well-being. Poultry genetics, breeding and biotechnology. W. M. Muir and S. Aggrey, ed. CABI Publ., Wallingford, UK, Pages 221-245.

Feddes, J.J.; Emmanuel, E.J. and Zuidhoft, M.J. (2002): Broiler performance, body weight variance, feed and water intake, and carcass quality at different stocking densities. Poult. Sci., 81: 774-779.

Ferket, P.R. (2004): Alternatives to antibiotics in poultry production: Responses, practical experience and recommendations. In: Nutritional Biotechnology in the Feed and Food Industries. Lyons TP, Jacques KA (eds). Nottingham University Press, Nottingham, UK., pp. 57-67.

Foroughi, R.; Hosin, M.T. and Hassan S. (2011): The Effect of Essential Oil of Thyme (Thimus vulgaris) on to Performance and Humoral Immune Response Broilers Chicken. Agricultural Journal, 6,6, 299-302.

Gross, W.B. and Siegel, H.S. (1983): Evaluation of the heterophil/lymphocyte ratio as a measure of stress in chickens. Avian Diseases, 27: 972-979.

Hagmuller, W.; Jugl-Chizzola, M.; Zitterl-Eglseer, K.; Gabler, C.; Spergser, J.; Chizzola, R. and Franz, C. (2006): The use of Thymi Herba as feed additive $(0.1 \%, 0.5 \%, 1.0 \%)$ in weanling piglets with assessment of the shedding of haemolysing E. coli and the detection of thymol in the blood plasma. Berl. Munch. Tierarztl. Wochenschr., 119: 50-54.

Hernandez, F.; Madrid, J.; Garcia, V.; Orengo, J. and Megías, M.D. (2004): Influence of two plant extracts on broilers performance, digestibility, and digestive organ size. Poultry Science, 83: 169-174.

Hocking, P.M. (1993): Welfare of broiler breeder and layer females subjected to food and water restriction during rearing: quantify the degree of restriction. Br. Poult. Sci., 34: 53-64.

Hocking, P.M.; Huaghes, B.O. and Keer-Keer, S. (1997): Comparision of food intake, rate of consumption, pecking activity and behaviour in layer and broiler breeder males. Br. Poult. Sci., 38 (3): 237-240.

Horton, G.M.J.; Fennell, M.J. and Prasad, B.M. (1991): Effects of dietary garlic (Allium sativum) on performance, carcass composition and blood chemistry changes in broiler chickens. Canadian Journal of Animal Science, 71: 939-942

Hui, Y.H. (1996): Oleoresins and essential oils. In: Hui YH, editor. Bailey's industrial oil and fat products. New York: Wiley-Interscience Publication ; cap.6, p.145-153. 
Issa, K.J. and Abo-Omar, J.M. (2012): Effect of garlic powder on performance and lipid profile of broilers. Open Journal of Animal Sciences, 2 (2): 62-68.

Javandel, F.; Navidshad, B.; Seifdavati, J.; Pourrahimi, G.H. and Baniyaghoub, S. (2008): The favorite dosage of garlic meal as a feed additive in broiler chickens ratios. Pak. J. Biol. Sci., 11: 1746-1749.

Javed, M.; Durrani, F.; Hafeez, A.; Khan, R.U. and Ahmed, I. (2009): Effect of aqueous extract of plant mixture oncarcass quality of broiler chicks. ARPN Journal of Agri. And Biol. Sci. 4: 37-40.

Jones, R.B. (1986): The tonic immobility reaction of the domestic fowl: a review. World's Poultry Science Journal, 42: 82-96.

Jones, R.B. (1987): The assessment of fear in the domestic fowl. In: R. Zayan and I.J.H. Duncan (Editors). Cognitive Aspects of Social Behaviour in the Domestic Fowl, Elsevier, Amsterdam. pp. 40-81.

Jones, R.B. (1996): Fear and adaptability in poultry: insights, implications and imperatives. Wld's. Pouh. Sci. J., 52: 131-174.

Jones, R.B. and Faure, J.M. (1981): Tonic immobility (righting time) in laying hens housed in cages and pens. Appl Anim Ethol. 7: 369-72.

Konjufca, V.H.; Pesti, G.M. and Bakalli, R.I. (1997): Modulation of cholesterol levels in broiler meat by die-tary garlic and copper. Poultry Science, 76: 1264-1271.

Kumar, S.; Sharadamma, K.C. and Radhakrishna, P.M. (2010): Effects of a garlic active based growth promoter on growth performance and specific pathogenic intestinal microbial counts of broiler chicks. Int. J. Poult. Sci., 9: 244-246.

Lane, $R$. (1987): Abnormal findings in avian hematology. Proceedings of First International Conference on Zoological and Avian Medicine, Oahu, HI., Pages 287-289.

Langhout, P. (2000): New additives for broiler chickens. World Poult. Elsevier, 16 (3): 22-27.

Lee, H.Y. and Craig, J.V. (1990): Beak-trimming effects on the behaviour and weight gain of floor-reared, egg strain pullets from three genetic stocks during the rearing period. Poult. Sci., 69: 568-575.

Lee, E. and Surh, Y.J. (1998): Induction of Apoptosis in HL-60 Cells by Pungent Vanilloids, [6]gingerol and [6]-paradol. Cancer Let., 134 (2): 163-168.

Lee, K.W.; Everts, H.; Kappert, H.J.; Wouterse, H.; Frehner, M. and Beynen, A.C. (2004): Cinnamanaldehyde, but not thymol, counteracts the carboxymethyl celluloseinduced growth depression in female broiler chickens. Int. J. Poult. Sci., 3: 608-612.
Lewis, M.R.; Rose, S.P.; Mackenzie, A.M. and Tucker, L.A. (2003): Effects of dietary inclusion of plant extracts on the growth performance of male broiler chickens. Brit. Poult. Sci. 44 (Suppl.): 43-44.

Mahmood, S.; Hassan, M.M.; Alam, M. and Ahmed, F. (2009): Comparative efficacy of Nigella sativa and Allium sativum as growth promototes in broilers. Int. J. of Agri. And Biol. 11: 775-778.

Mansoub, N.H. (2011): Comparative effects of using garlic as probiotic on performance and serum composition of broiler chickens. Annals of Biological Research. 2: 486-490.

Martrenchar, A.; Morisse, J.P.; Huonnic, D. and Cotte, J.P. (1997): Influence of stocking density on some behavioural, physiological, and productivity traits of broilers. Vet. Res., 28: 473-480.

Maxwell, M.H. (1993): Avian blood leucocyte responses to stress. World's Poultry Science Journal, 49: 34-43.

Maxwell, M.H. and Robertson, G.W. (1998): The avian heterophil leucocyte: a review. World's Poultry Science Journal, 54: 155-178.

Maxwell, M.H.; Robertson, G.W.; Anderson, I.A.; Dick, L.A. and Lynch, M. (1991): Haematology and histopathology of seven-week-old broilers after early food restriction. Res. Vet. Sci., 50: 290-297.

McFarlane, J.M. and Curtis, S.E. (1989): Multiple concurrent stressors in chicks. 3. Effects on plasma corticosterone and the heterophil : lymphocyte ratio. Poult. Sci., 68: 522-527

Mikulski, D.; Zdunczyk, Z.; Jankowski, J. and Juskiewicz, J. (2008): Effects of organic acids or natural plant extracts added to diets for turkeys on growth performance, gastrointestinal tract metabolism and carcass characteristics. J. Anim. Feed Sci., 17: 233-246

Mills, A.D. and Faure, J.M. (1991): Divergent selection for duration of tonic immobility and social reinstatement behavior in Japanese quail (Coturnix coturnix japonica) chicks. J. Comp. Psychol. 105: 25-38.

Mohebbifar, A. and Torki, M. (2011): Growth performance and humoral response of broiler chicks fed diet containing graded levels of ground date pits and garlic and thyme. Global Veterinaria, 6: 389-398.

Najafi, P. and Torki, M. (2010): Performance, blood metabolites and immunocompetaence of broiler chicks fed diets included essentioal oils of medicinal herbs. J. Anim. Vet. Adv., 9: 1164-1168.

Nascimento, G.F.; Locatelli, J.; Freitas, P.C. and Silva, G.L. (2000): Antibacterial activity of plant extracts and phytochemicals on antibiotic-resistant bacteria. Brazil. J. Microbiol. 31(4): 247-256. 
NOAH, (National Office of Animal Health) (2001): Antibiotics for animals. http://www.noah.co.uk/issues/antibiotics.htm

NRC, (1994): National Research Council. Nutrient Requirements of Poultry. 9th edn., National Academy Press. Washington, DC., USA.

Onibi, G.E.; Oluwatoyin, E.A.; Adebowale, N.F. and Ayodeji, V.A. (2009): Response of broiler chickens in terms of performance and meat quality to garlic (Allium sativum) supplementation. African Journal of Agricultural Research,4 (5): 511-517.

Papageorgiou, G.; Botsoglou, N.; Govaris, A.; Giannenas, I.; Iliadis, S. and Botsoglou, E. (2003): Effect of dietary oregano oil and $\alpha$ tocopheryl acetate supplementation on ironinduced lipid oxidation of turkey breast, thigh, liver and heart tissues. J. Anim. Physiol. Anim. Nutr., 87: 324-335.

Pourali, M.; Mirghelenj, S.A. and Kermanshahi, $H$. (2010): Effect of Garlic Powder on Productive Performance and Immune Response of Broiler Chickens Challenged with Newcastle Disease Virus. Global Veterinaria 4 (6): 616-621.

Qureshi, A.A.; Abuirmeileh, N.; Din, Z.Z.; Elson, C.E. and Burger, W.C. (1983): Inhibition of cholesterol and fatty acid biosynthesis in liver enzymes and chicken hepatocytes by polar fractions of garlic. Lipids., 18: 343- 348.

Rahimi, S.; Teymouri Zadeh, Z.; Karimi Torshizi, M.A.; Omidbaigi, R. and Rokni, H. (2011): Effect of the Three Herbal Extracts on Growth Performance, Immune System, Blood Factors and Intestinal Selected Bacterial Population in Broiler Chickens J. Agr. Sci. Tech., 13: 527539

Rahmatnejad, E.; Roshanfekr, H.; Ashayerizadeh, O.; Mamooee, M. and Ashayerizadeh, A. (2009): Evaluation the effect of several non-antibiotic additives on growth performance of broiler chickens. J. Anim. Vet. Adv., 8: 1670-1673.

Ramakrishna, R.R.; Platel, K. and Srinivasan, K. (2003): In vitro influence of spices and spiceactive principles on digestive enzymes of rat pancreas and small intestine. Nahrung, 47: 408-412.

Sarica, S.; Ciftci, A.; Demir, E.; Kilinc, K. and Yildirim, $Y$. (2005): Use of an antibiotic growth promoter and two herbal natural feed additives with and without exogenous enzymes in wheat based broiler diets. South African Jour-nal of Animal Science, 35: 61-72.

Saxena, M.J. and Manden, p. (1997): Herbals for stress management in pets. The Vet., 21 (1): $11-14$.
Sivam, G.P. (2001): Protection against helicobacter pylori and other bacterial infections by garlic. Journal of Nutri-tion, 131:1106-1108.

Songsanga, A.; Adcharatt, S.; Usa, O.; Reawadee, S.; Penpak, P.; Sawanit, C. and Wunchai, P. (2008): Effect of Garlic (Allium sativum) Supplementation in Diets of Broilers on Productive Performance, Meat Cholesterol and Sensory Quality. Tropentag 2008 University of Hohenheim, October 7-9,. Conference on International Research on Food Security, Natural Resource Management and Rural Development

SPSS: Statistical Package for Social Sciences (1999): Release 10.0.1 version. SPSS Inc.

Stoilova, I.; Krastanov, A.; Stoyanova, A.; Denev, P. and Gargova, S. (2007): Antioxidant Activity of a Ginger Extract (Zingiber officinale). Food Chem., 102 (3): 764-770

Toghyani, M.; Mohsen, T.; Abas, A.G. and Sayed, A.T. (2010): Performance, immunity, serum biochemical and hematological parameters in broiler chicks fed dietary thyme as alternative for an antibiotic growth promoter. African Journal of Biotechnology, 9(40): 19-6825.

Tollba, A.A.H. and Hassan, M.H. (2003): Using some natural additives to improve physiological and productive performance of broiler chicks under high temperature conditions. Black cumin (niglla sativa) or Garlic (allium sativum). Poultry Science, 23: 327-340.

Vestergaard, K.S. and Sanotra G.S. (1999): Relationships between leg disorders and changes in the behaviour of broiler chickens. Vet Rec. 144 (8):205- 9.

Vincent, H.V. (2002): Carvacrol and thymol reduce swine waste odour and pathogens stability of oils. Curr. Microbiol. 44: 38-43.

Wintrobe, M. M. (1976): Classics: Macroscopic examination of the blood. Am. J. Med. Sci., 271: 90- 101.

Zulkifli, I.; Chenorma, M.T.; Chong, and Loh, T.C. (2000): Heterophil to lymphocyte ratio and tonic immobility reactions to preslaughter handling in broiler treated with ascorbic acid. Poultry Science, 79: 402-406.

Zulkifli, I.; Liew, P.K.; Israf, D.A.; Omar, A.R. and Hair-Bejo, M. (2003): Effect of early age feed restriction and heat conditioning on heterophil/lymphocyte ratios, heat shock protein 70 expression and body temperature of heat-stressed broiler chickens. J. Therm. Biol., 28: 217-222. 
تأثير استخدام الزيوت الأساسية كمفز للنمو في الغذاء علي السلوكيات و الأراحة و الأداء في بدارى التسمين

\section{سامح جاد عبد الحق رمضان}

أجريت هذة الدر اسة على عدد 150 فرخ من فر اخ التسمين عمر يوم حيث تم توزيعهم عشو ائيا على خمس معاملات غذائية

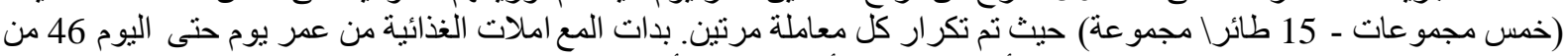

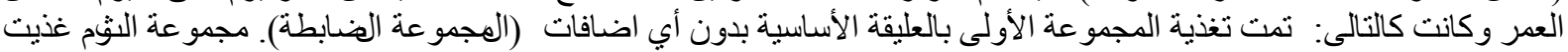

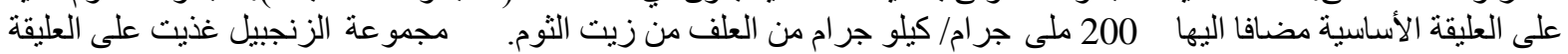

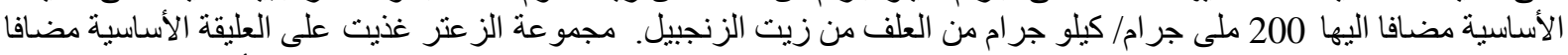

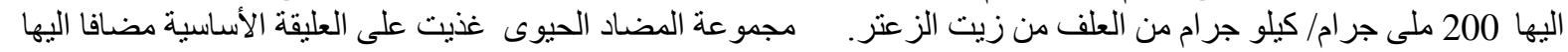

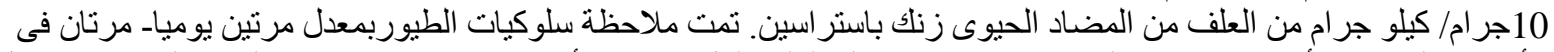

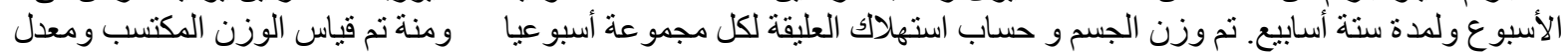

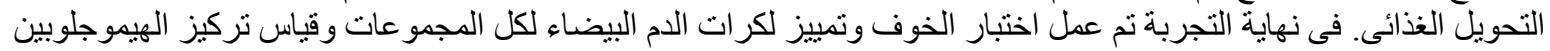

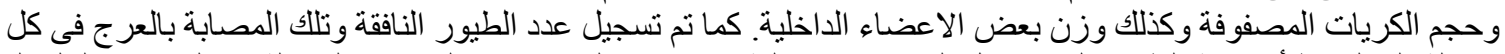

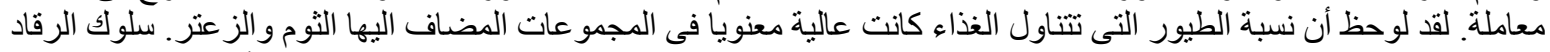

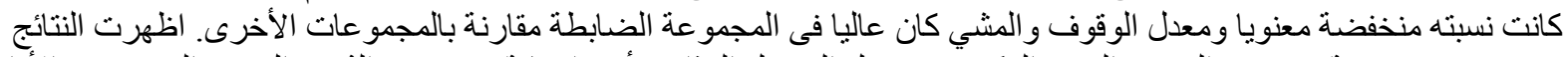

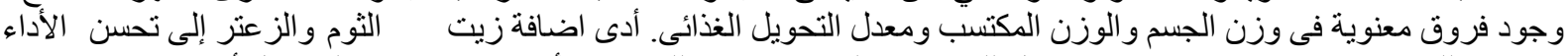

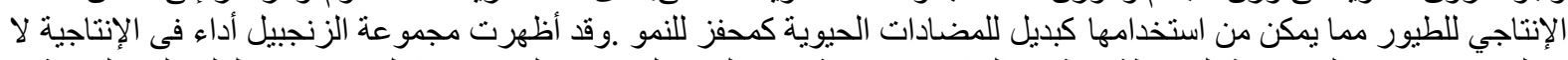

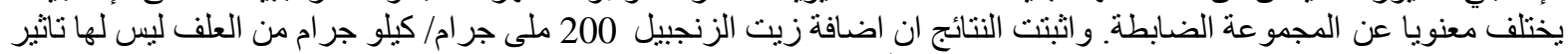

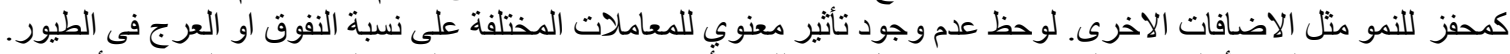

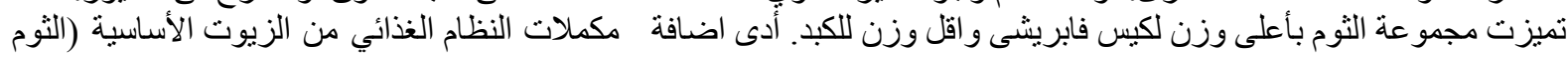
و الزنجبيل و الزعتر ) و المضادات الحيوية في تحسين راحة ورئ ورفاهية الحيوان وتقليل الإجهاد و الخوف. 